\title{
Research of Sulfuric Acid Leaching of Copper Off-Balance Ores
}

\author{
Aminjanova S.I., Muratova M.I., Mirzajonova S.B., Karimova T.P., Saidova M.S.
}

\begin{abstract}
In this article are considered possibility of drawing into treatment off-balance copper ore for the purpose after extraction from their valuable components. On the basis of learning chemical and mineralogical compounds off-balance ores are defined, what optimal ways their treatment are piles leaching. Shown results by sulfuric acid leaching minerals of copper considered in consist of off-balance ores and defined, what optimal conditions sulfuric acid leaching are concentration sulfuric acid 50-75 g/l, duration 15 days, degree of extraction oxide copper from solution is $98,5-99 \%$, sulfuric copper is $5,6 \%$
\end{abstract}

Keywords: off-balance copper ores, harmful influence, leaching process, heap leaching organization (HL), iron (III) sulfate solution, copper recovery degree, dynamic equilibrium of leaching process.

\section{INTRODUCTION}

$\mathrm{I}_{\mathrm{n}}$ the conditions of independence, the mining and metallurgical industry of the Republic faced a whole complex of difficult problems. This is, first of all, a complete depletion of rich and easily opened ore deposits, an increase in environmental protection requirements, an increase in the demand for non-ferrous metals, including copper and its associated elements. Increasing the complexity of raw materials use, disposal of all valuable components, development and introduction of waste-free technologies becomes an urgent problem.

At present, reserves of non-ferrous metals concentrated in dumps and tailings stores at JSC Almalyk MMC are estimated at hundreds of millions of tons. In particular, about 150 million tons of non-standard off-balance-sheet ores have accumulated in the dumps of Almalyk Mining and Metallurgical Complex (AMMC). Non-standard ores accumulate in dumps, and in the subsoil of deposits remain as

Revised Manuscript Received on December 30, 2019.

* Correspondence Author

Aminjanova Sevara Islamovna*, Senior Teacher, Department of Mining engineering, Tashkent state technical university, University Street 2, Tashkent, Uzbekistan 100095Email: sevara-aminjanova@mail.ru Phone number: 99894 677-67-49

Muratova Matlyuba Isaxidjanovna, Senior Teacher, Department of Geological engineering, Tashkent State Technical University, Tashkent, Uzbekistan.

Mirzajonova Saodat Bakidjanovna, Senior Teacher, Department of Metallurgy, Tashkent State Technical University, Tashkent, Uzbekistan.

Karimova Tursunoy Parkatovna, Senior Teacher, Department of Metallurgy, Tashkent State Technical University, Tashkent, Uzbekistan.

Saidova Malika Sayfullyevna, Senior Teacher, Department of Metallurgy, Tashkent State Technical University, Tashkent, Uzbekistan.

(C) The Authors. Published by Blue Eyes Intelligence Engineering and Sciences Publication (BEIESP). This is an open access article under the CC BY-NC-ND license (http://creativecommons.org/licenses/by-nc-nd/4.0/) mining losses. Said raw material contains a large amount of non-ferrous, rare and noble metals and can be usefully used [1].

There is another aspect to this problem. The dumps of off-balance and off-grade ores are a long-term source of environmental pollution due to spontaneous leaching of copper, zinc, lead, molybdenum, arsenic and other metals.

Thus, existing dumps should be considered not only, but in some cases not so much as sources of metal extraction, but above all as environmentally hazardous objects.

The most rational way to get rid of the harmful impact of such objects on the environment is to intensify the natural leaching process by organizing heap leaching (HL).

Only after "depleted" dumps by forced leaching can the reclamation of dumps or the use of rock as building materials be recommended. Thus, heap leaching is intended to solve two problems simultaneously: to expand the raw material base of production of metals and construction materials and to improve the ecology of these areas [2-5].

\section{RELETED WORK}

In order to determine the possibility of extracting copper and other valuable components, studies were carried out on sulphuric acid leaching of oxidized off-balance-sheet ore of "Kalmakyr" deposit.

The study of the chemical and mineral composition of the ore showed that copper in oxidized ores is present - in the form of malachite, cuprite, tenorite. Copper-containing minerals are in fine germination with silicates of containing rocks and other minerals of non-ferrous metals and iron. The copper content usually does not exceed $0.5 \%$, but mainly amounts to tenths of a percent.

In order to establish the regularities of physical and chemical processes, the influence of the following main factors on the results of leaching of minerals and ores was analyzed: size of ore mass, structural features of ore mass, concentration of solvent, concentration of intensifiers.

In hydrometallurgical processes physical and chemical processes proceed in water and salt solutions. This type of reactions in some cases proceeds with participation of organic solvents or sorbents at normal or elevated pressures in the conditions of temperatures $20-200{ }^{\circ} \mathrm{C}$ [2].

Leaching of malachite and oxidized copper ore occurs in a wide range of temperatures, even at their negative values, which determines the possibility of using heap leaching. Leaching of sulphide ores is effective only at high positive temperatures. As a result of studying kinetic regularities of leaching of sulphide, mixed and oxidized ores at $20^{\circ} \mathrm{C}$ temperature, size of ore mass - $1000 \mathrm{~mm}$, concentration of sulfuric acid 5\%, the following dependencies were established:

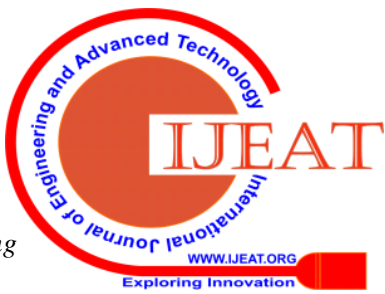




\section{Research of Sulfuric Acid Leaching of Copper Off-Balance Ores}

$\mathrm{E}=2,68 \cdot \mathrm{d}^{-0,5029} \cdot \tau^{1,2 \cdot d^{0,48}}-$ For sulfide ore;

$\mathrm{E}=0,33 \cdot \mathrm{d}^{0,0364} \cdot \tau^{0,22 \cdot d^{-0,01}}$ - For oxidized copper ore;

$\mathrm{E}=0,31 \cdot \mathrm{d}^{0,1673} \cdot \tau^{0,17 \cdot \mathrm{d}^{-0,49}}$ - For mixed ore,

Where, $\mathrm{E}$ is copper recovery to solution,\%;

$\mathrm{d}$ - is size of leachable material, $\mathrm{mm}$;

$\tau$ - Leaching duration, day;

When the maximum size of the ore piece is $250 \mathrm{~mm}$, which is required to achieve the 50-percentage recovery, the leaching time of the oxidized copper ore is 20 days.

When selecting the solvent for heap leaching of ore, many factors are taken into account, of which the main factors are:

1) chemical and physical nature of ore;

2) solvent cost;

3) corrosive effect of the solvent on the equipment;

4) selectivity of solvent action with respect to leached product;

5) possibility of solvent regeneration.

As can be seen from the above data, sulfuric acid is most suitable for leaching off-balance oxidized ores. Sulfuric acid is a good solvent of oxidized copper minerals $\left(\mathrm{Cu}_{2} \mathrm{O}, \mathrm{CuO}\right)$. And sulfuric acid is characterized by low cost and has relatively low corrosion effect on hydrometallurgical equipment.

\section{OBJECTS AND METHODS OF RESEARCH}

Features of behaviour of accompanying copper valuable components in sulfuric acid solutions in order to ensure complete separation of copper into a separate product and selectivity of copper extraction.

When leaching a product sulfuric acid, besides above the specified reactions, reactions with participation of the main minerals and impurity proceed ( $\left.\mathrm{FeO}, \mathrm{ZnO}, \mathrm{PbO}, \mathrm{Fe}_{2} \mathrm{O}_{3}\right)$ :

$$
\mathrm{ZnO}+\mathrm{H}_{2} \mathrm{SO}_{4}=\mathrm{ZnSO}_{4}+\mathrm{H}_{2} \mathrm{O}
$$

$$
\mathrm{PbO}+\mathrm{H}_{2} \mathrm{SO}_{4}=\mathrm{PbSO}_{4}+\mathrm{H}_{2} \mathrm{O}
$$

Impurities such as iron oxide also dissolve:

$$
\mathrm{Fe}_{2} \mathrm{O}_{3}+3 \mathrm{H}_{2} \mathrm{SO}_{4} \rightarrow \mathrm{Fe}_{2}\left(\mathrm{SO}_{4}\right)_{3}+3 \mathrm{H}_{2} \mathrm{O}
$$

The resulting $\mathrm{Fe}_{2}\left(\mathrm{SO}_{4}\right) 3$ react with copper compounds:

$$
\mathrm{CuS}+\mathrm{Fe}_{2}\left(\mathrm{SO}_{4}\right)_{3}=\mathrm{CuSO}_{4}+2 \mathrm{FeSO}_{4}+\mathrm{S}^{0}
$$$$
\mathrm{Cu}_{2} \mathrm{~S}+2 \mathrm{Fe}_{2}\left(\mathrm{SO}_{4}\right)_{3}=2 \mathrm{CuSO}_{4}+4 \mathrm{FeSO}_{4}+\mathrm{S}^{0}
$$

$3 \mathrm{CuO}+\mathrm{Fe}_{2}\left(\mathrm{SO}_{4}\right)_{3}+3 \mathrm{H}_{2} \mathrm{O}=3 \mathrm{CuSO}_{4}+2 \mathrm{Fe}(\mathrm{OH}$

Metallic copper dissolves well in the presence of ferric sulfate in acidified solutions:

$$
\mathrm{Cu}+\mathrm{Fe}_{2}\left(\mathrm{SO}_{4}\right)_{3}=\mathrm{CuSO}_{4}+2 \mathrm{FeSO}_{4}
$$

The ferric (III) sulfate solution is a good solvent for many natural copper sulfides. However, this solvent has no independent significance in copper hydrometallurgy. The reason for this is hydrolysis of $\mathrm{Fe}_{2}\left(\mathrm{SO}_{4}\right)_{3}$ in aqueous solutions. The solutions must be acidified with sulfuric acid to make the sulfate stable.

With the combined effects of these reagents on sulfide minerals, $\mathrm{Fe}_{2}\left(\mathrm{SO}_{4}\right)_{3}$ acts as a sulfide oxidizer and sulfuric acid is their actual solvent.

Oxide iron, when oxygen is present in the pulp, is again oxidized to oxide iron by reaction

$4 \mathrm{FeSO}_{4}+\mathrm{O}_{2}+\mathrm{H}_{2} \mathrm{SO}_{4}=2 \mathrm{Fe}_{2}\left(\mathrm{SO}_{4}\right)_{3}+2 \mathrm{H}_{2} \mathrm{O}$,

(8)

Ferric sulfate is reduced to $\mathrm{FeSO}_{4}$. The reverse oxidation of the $\mathrm{FeSO}_{4}$ to $\mathrm{Fe}_{2}\left(\mathrm{SO}_{4}\right)_{3}$ to regenerate the solvent is accomplished by air blowing.

Thus, there is always some ferric sulfate-sulfide oxidizer in the pulp, but the dissolution of the sulfides is slower than the dissolution reaction of the oxides. This makes it possible to further oxidize copper minerals.

It has been found that the change in the concentration of ferric iron in the solution and the change in the size of the mineral have practically no effect on the extraction of copper into the solution. A significant increase in copper recovery to the solution is observed as the temperature increases. Thus, in one day of leaching, $22 \%$ is extracted during $35^{\circ} \mathrm{C}$, and $32 \%$ of copper is extracted during $50^{\circ} \mathrm{C}$.

The results of experiments given on fig. 1, 2 and in tab. 1 show that when leaching a product solution of sulfuric acid, extraction of copper in solution reaches $\% \approx 58.8$.

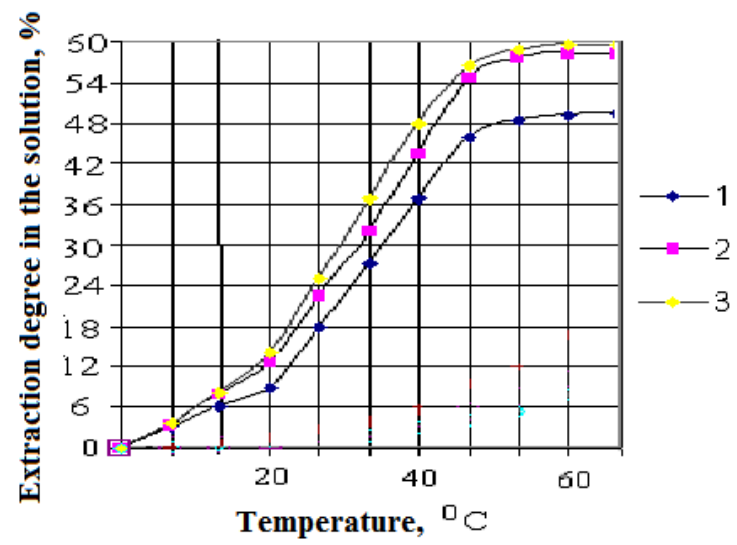

Fig. 1. Kinetics of copper leaching from ore with $\mathrm{H}_{2} \mathrm{SO}_{4}$ solution, g/l: 1-25; 2-50; 3-75; 4-100

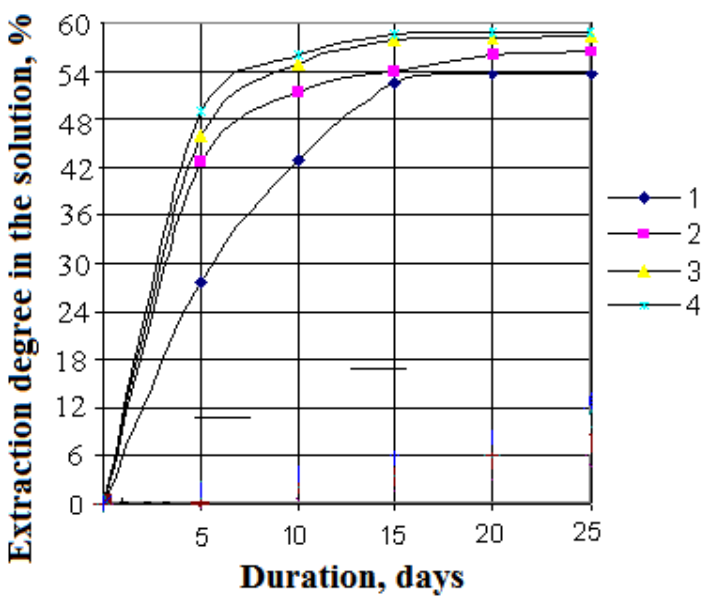

Fig. 2. The degree of copper extraction into the solution depends on the temperature at different duration of the test, the number of days: $1-5 ; 2-10$; $3-15$; $\mathrm{CH}_{2} \mathrm{SO}_{4}-75 \mathrm{~g} / \mathrm{l}$

The degree of recovery of copper during natural leaching is dependent on the concentration of sulfuric acid and the duration of the experiments (Table 1). As can be seen from the results of the experiments, the concentration of sulfuric acid $50-75 \mathrm{~g} / \mathrm{l}$ is optimal.

The study of the effect of the duration of the process on the leaching of copper from the product with a sulfate solution with a concentrate of $100 \mathrm{~g} / \mathrm{l}$ at various temperatures shows that during the initial period (up to 5 days) the transition of copper into the solution takes place very intensively 10-15 minutes.

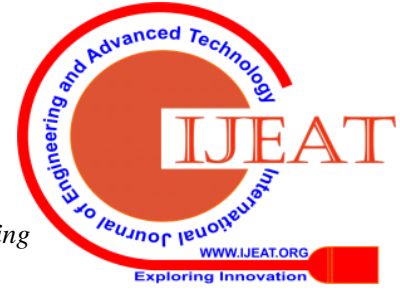


Dynamic equilibrium of leaching process is established (Table 1, Figure 3). Increasing the contact time of the sulfuric acid solution and ore may

Lead to an increase in impurities in the solution. When leaching ore with sulfuric acid, oxidized copper minerals react primarily.

Iron minerals and copper sulfides react slowly with sulfuric acid. Therefore, in order to achieve maximum copper recovery with minimal transition to the impurities solution, the leaching time was selected for 15 days (Table 1, Figure 3).

The higher the concentration of sulfuric acid, the faster it is consumed for dissolution reactions, since not only copper compounds but also other minerals are completely dissolved, which increases the useless consumption of acid.

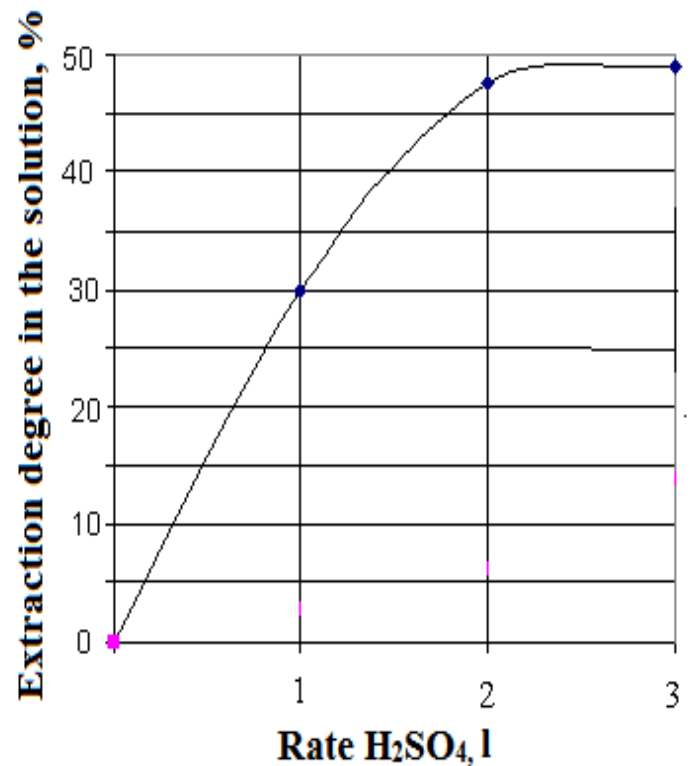

Fig. 3. Dependence of extraction of copper on $\mathrm{H}_{2} \mathrm{SO}_{4}$ expense on $0,05 \mathrm{~m}^{3}$ of ore

As the concentration of sulfuric acid in the solution increases (up to $75 \mathrm{~g} / \mathrm{l}$ ), the solubility of the constituent ores increases linearly and reaches a maximum. A further increase in concentration (from $75 \mathrm{~g} / \mathrm{l}$ ) does not increase the rate of copper dissolution and even, on the contrary, after some time causes a slight slowdown in the process (Figure 3). Increasing the concentration of sulfuric acid from $75 \mathrm{~g} / \mathrm{l}$ only slightly affects the dissolution of copper. In order to leach the ore with sulfuric acid, we recommend that the concentration of sulfuric acid not exceed $75 \mathrm{~g} / \mathrm{l}$, thus optimizing the degree of dissolution of the concomitant minerals.

Irrigation density has a significant effect on the leaching process. As it increases, the concentration of copper in the productive solution decreases. On the basis of the test, it was found that in order to achieve an optimal ratio between the copper content in the productive solution and the existing processing capacity, it is necessary to differentiate the irrigation density over time (Figure 4).

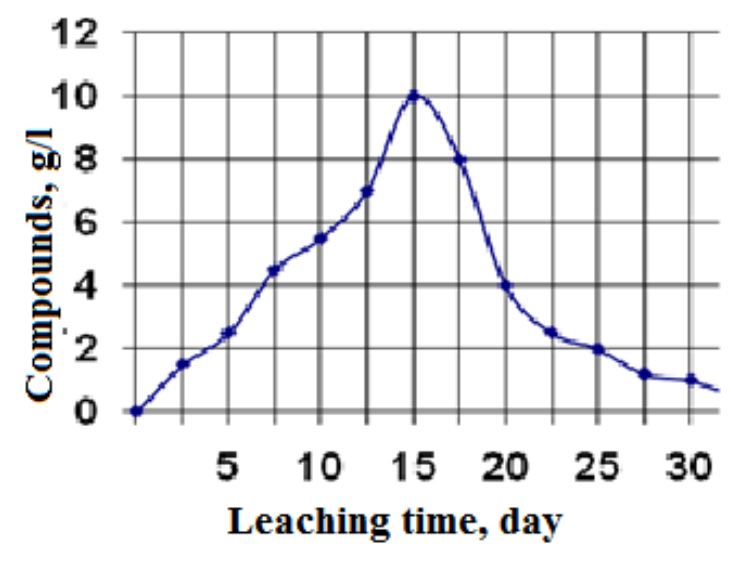

Fig. 4. Change in copper concentration in solution over time

\section{RESULTS OF THE RESEARCH}

Table 1Results of studies on heap leaching of off-balance-sheet ores

\begin{tabular}{|c|c|c|c|c|c|c|}
\hline 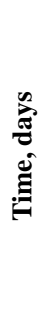 & 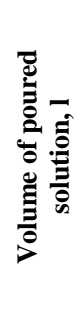 & 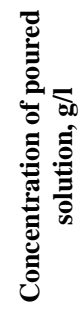 & 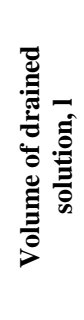 & 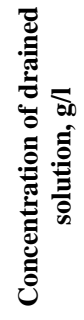 & 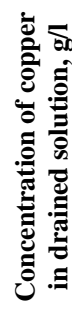 & 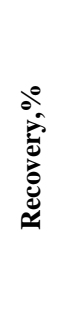 \\
\hline 1 & 2 & 3 & 4 & 5 & 6 & 7 \\
\hline 1 & 3,20 & 50 & 2,20 & 2,55 & 1,65 & 12,70 \\
\hline 3 & 0,50 & 50 & 0,35 & 2,44 & 2,14 & 18,40 \\
\hline 5 & 0,50 & 50 & 0,30 & 1,90 & 2,00 & 23,70 \\
\hline 8 & 0,50 & 50 & 0,25 & 2,03 & 1,25 & 28,50 \\
\hline 10 & 0,60 & 50 & 0,45 & 2,90 & 0,58 & 31,80 \\
\hline 15 & 1,00 & 50 & 0,85 & 3,15 & 1,65 & 33,70 \\
\hline 1 & 3,20 & 75 & 2,10 & 5,75 & 1,75 & 15,50 \\
\hline 3 & 0,50 & 75 & 0,40 & 7,50 & 2,10 & 25,10 \\
\hline 5 & 0,50 & 75 & 0,35 & 5,90 & 2,50 & 36,50 \\
\hline 8 & 0,50 & 75 & 0,35 & 8,25 & 2,05 & 43,40 \\
\hline 10 & 0,60 & 75 & 0,55 & 10,10 & 1,50 & 51,50 \\
\hline 15 & 1,00 & 75 & 0,80 & 9,55 & 2,25 & 58,80 \\
\hline
\end{tabular}

\section{CONCLUSION}

Thus, the following optimal conditions of ore leaching were established: concentration of sulfuric acid 50 - 75 g/l, duration 15 days.

Under these conditions, the degree of recovery of copper oxides into the solution is $98,5-99 \%$, copper sulfides $5,6 \%$.

The sulfuric acid leach cake contains $0,14 \%$ copper in the form of sulfide, that is, it is obvious that the copper oxides have completely converted to the sulfuric acid solution and the sulfides have remained in a small amount in the solid phase.

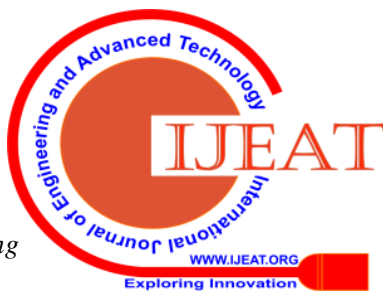




\section{REFERENCES}

1. Sanakulov K.S. Scientific and technical bases of processing of wastes of mining and metallurgical production. - T.: FAN AN RUz, 2009. 405 p.

2. Matkarimov, S. T., Nosirkhudjayev, S. Q. U., Ochildiyev, Q. T., Nuraliyev, O. U. U., \& Karimdjonov, B. R. (2019). Technological processes of receiving metals in the conditions of moderate temperatures. International Journal of Innovative Technology and Exploring Engineering, 8(12), 1826-1828. https://doi.org/10.35940/ijitee.L2856.1081219.

3. Matkarimov S.T., Berdiyarov B.T., Yusupkhodjayev A.A. "Technological Parameters of the Process of Producing Metallized Iron Concentrates from Poor Raw Material,” Int. J. Innov. Technol. Explor. Eng., vol. 8, no. 11, pp. 600-603, Sep. 2019.

4. Dementyev V.E., Druzhinin G.J. Gudkov S.S. Kuchny leaching. Irkutsk: JSC "Irgiredmet," 2004. -352 p.

5. K.S. Sanakulov et al. Heap leaching of gold from multi-tier stacks. $-\mathrm{T}$.: "FAN," 2010. - 304.

\section{AUTHORS PROFILE}

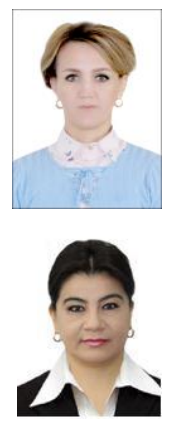

Aminjanova Sevara Islamovna, Senior Teacher, Department of Mining engineering, Tashkent state technical university, University Street 2, Tashkent, Uzbekistan 100095Email: sevara_aminjanova@mail.ru Phone number: 99894 677-67-49

Muratova Matlyuba Isaxidjanovna, Senior Teacher, Department of Geological engineering, Tashkent State Technical University, Tashkent, Uzbekistan.

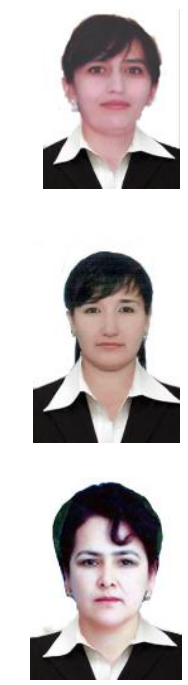

Mirzajonova Saodat Bakidjanovna, Senior Teacher, Department of Metallurgy, Tashkent State Technical University, Tashkent, Uzbekistan.

Karimova Tursunoy Parkatovna, Senior Teacher, Department of Metallurgy, Tashkent State Technical University, Tashkent, Uzbekistan.

Saidova Malika Sayfullyevna, Senior Teacher, Department of Metallurgy, Tashkent State Technical University, Tashkent, Uzbekistan. 